\title{
Psychosocial work environment and cardiovascular risk factors in an occupational cohort in France
}

Isabelle Niedhammer, Marcel Goldberg, Annette Leclerc, Simone David, Isabelle Bugel, Marie-France Landre

\begin{abstract}
Study objective-Concordant results have been reported in several studies for the effects of job stress on cardiovascular disease, but the potential mechanisms of these effects have seldom been explored. The aim of this study was therefore to examine, in women and men, the cross sectional relations between psychosocial work variables (psychological demands, decision latitude, and social support) and cardiovascular risk factors (hypertension, hyperlipidaemia, diabetes, overweight, smoking, and alcohol consumption).

Participants-The original cohort comprised 20625 volunteers (men aged from 40 to 50 and women from 35 to 50 ) employed by the French Company Electricité De France - Gaz De France and followed up yearly since 1989 . The study was restricted to the 13226 volunteers in the cohort who were still working and answered a self administered questionnaire on psychosocial work factors in 1995.

Design-Data were based on replies to this questionnaire. Three psychosocial work environment exposure scores were used to assess psychological demands, decision latitude, and social support at work respectively. The main outcome measures were the prevalence of hypertension, hyperlipidaemia, and diabetes within the previous 12 months, overweight, smoking, and alcohol consumption.
\end{abstract}

Main results-Psychosocial work factors were significantly associated with hypertension, hyperlipidaemia, overweight, smoking, and alcohol consumption, but not with diabetes. In men, low decision latitude was associated with hypertension, high decision latitude and high social support with overweight, low decision latitude with alcohol consumption. Moreover, the risk of hyperlipidaemia increased in men exposed to both high psychological demands and low social support. In women, low decision latitude was related to hyperlipidaemia, high psychological demands with overweight, high psychological demands and high decision latitude with smoking, and low social support with alcohol consumption.

Conclusions-These cross sectional results underline the potential effects of psychosocial work characteristics on cardiovascular risk factors and the differences between the effects of job stress in men and women, and confirm the direct mechanisms (through physiological variables) and indirect mechanisms (through behavioural risk factors) potentially involved in the relation between psychosocial work characteristics and cardiovascular disease.

\section{(F Epidemiol Community Health 1998;52:93-100)}

Since the publication in 1979 of the study by Karasek, ${ }^{1}$ a number of authors ${ }^{2-15}$ have examined the relation between the organisation of work and cardiovascular morbidity and mortality. Except for Reed et $a l^{14}$ and Alterman et $a l,{ }^{15}$ all these authors ${ }^{2-13}$ found consistent results showing an excess risk for cardiovascular disease among people exposed to job strain, as defined by a combination of high levels of psychological demands and low levels of decision latitude. Two literature reviews ${ }^{16} 17$ have recently been published on the role of psychosocial work environment in cardiovascular disease. A critical article has also been written by Kasl very recently on the conceptual and methodological aspects. ${ }^{18}$

Two kinds of mechanisms might explain the relation between job strain and cardiovascular diseases: direct mechanisms, through physiological variables such as increased blood pressure ${ }^{19-25}$ and serum cholesterol ${ }^{12}$ increases in left ventricular mass, ${ }^{21}$ high concentrations of hormones, especially catecholamines, ${ }^{26}$ high plasma fibrinogen concentrations, ${ }^{27}$ high glycated haemoglobin concentrations, ${ }^{28}$ and indirect mechanisms, through behavioural risk factors such as smoking ${ }^{29}$ and drinking. However, social support at work might reduce the effects of job strain on cardiovascular disease, ${ }^{8}$ blood pressure ${ }^{31}$ or smoking. ${ }^{32}$

The aim of this study was to examine the cross sectional relations between the psychosocial work variables of psychological demands, decision latitude, and social support at work and the cardiovascular risk factors of hypertension, hyperlipidaemia, diabetes, overweight, smoking, and alcohol consumption, in a cohort of male and female workers employed by the French Company Electricité De France - Gaz De France (EDF-GDF) in a wide variety of occupations. 
Table 1 Study population in 1995

\begin{tabular}{|c|c|c|c|c|c|}
\hline & & \multicolumn{2}{|c|}{ Women $(n=3594)$} & \multicolumn{2}{|c|}{$\operatorname{Men}(n=9632)$} \\
\hline & & No & $\%$ & No & $\%$ \\
\hline \multicolumn{6}{|c|}{ Age group (years) } \\
\hline Women & Men & & & & \\
\hline $42-44$ & & 879 & 24.5 & - & - \\
\hline $45-49$ & $47-49$ & 1554 & 43.2 & 4275 & 44.4 \\
\hline $50-54$ & $50-54$ & 945 & 26.3 & 4557 & 47.3 \\
\hline $55-56$ & $55-56$ & 216 & 6.0 & 800 & 8.3 \\
\hline \multicolumn{6}{|c|}{ Marital status } \\
\hline Single & & 242 & 6.7 & 198 & 2.1 \\
\hline Married & & 2474 & 68.8 & 8579 & 89.1 \\
\hline Cohabitir & & 221 & 6.2 & 319 & 3.3 \\
\hline Separatec & & 75 & 2.1 & 97 & 1.0 \\
\hline Divorced & & 452 & 12.6 & 358 & 3.7 \\
\hline Widowed & & 130 & 3.6 & 78 & 0.8 \\
\hline \multicolumn{6}{|c|}{ No of children } \\
\hline 0 & & 388 & 10.9 & 502 & 5.2 \\
\hline 1 & & 1031 & 28.9 & 1802 & 18.8 \\
\hline 2 & & 1722 & 48.3 & 4371 & 45.7 \\
\hline 3 & & 348 & 9.8 & 2191 & 22.9 \\
\hline 4 or more & & 75 & 2.1 & 704 & 7.4 \\
\hline \multicolumn{6}{|c|}{ Education level } \\
\hline Primary & & 222 & 6.2 & 465 & 4.8 \\
\hline Lower vo & & 1761 & 49.0 & 4942 & 51.3 \\
\hline Lower se & & 685 & 19.1 & 1212 & 12.6 \\
\hline Upper se & & 413 & 11.5 & 625 & 6.5 \\
\hline Upper vo & & 199 & 5.5 & 673 & 7.0 \\
\hline Universit & & 255 & 7.1 & 1441 & 15.0 \\
\hline Other & & 59 & 1.6 & 273 & 2.8 \\
\hline \multicolumn{6}{|c|}{ Occupational group } \\
\hline Teaching & alth professionals & - & - & 126 & 1.3 \\
\hline Managers & & 253 & 7.0 & 1601 & 16.7 \\
\hline Engineer & & 178 & 5.0 & 2178 & 22.7 \\
\hline Health an & l work associate professionals & 75 & 2.1 & - & - \\
\hline Administ & ssociate professionals & 2008 & 56.1 & 1141 & 11.9 \\
\hline $\begin{array}{l}\text { Physical, } \\
\text { professior }\end{array}$ & ering and life science associate & - & - & 549 & 5.7 \\
\hline Foremen & & 371 & 10.4 & 2986 & 31.1 \\
\hline Clerks & & 695 & 19.4 & 270 & 2.8 \\
\hline Skilled in & 1 workers & - & - & 393 & 4.1 \\
\hline Craftsme & & - & - & 355 & 3.7 \\
\hline \multicolumn{6}{|c|}{ Physical exertion at work } \\
\hline Low & & 1158 & 33.0 & 2821 & 29.7 \\
\hline Medium & & 1464 & 41.7 & 3716 & 39.1 \\
\hline High & & 891 & 25.3 & 2964 & 31.2 \\
\hline \multicolumn{6}{|c|}{ Level of psychological demands } \\
\hline Low & & 1445 & 43.1 & 5096 & 55.1 \\
\hline High & & 1911 & 56.9 & 4147 & 44.9 \\
\hline \multicolumn{6}{|c|}{ Level of decision latitude } \\
\hline High & & 1623 & 47.7 & 4688 & 50.3 \\
\hline Low & & 1776 & 52.3 & 4641 & 49.7 \\
\hline \multicolumn{6}{|c|}{ Level of social support at work } \\
\hline High & & 1599 & 45.8 & 4567 & 48.5 \\
\hline Low & & 1893 & 54.2 & 4856 & 51.5 \\
\hline
\end{tabular}

\section{Methods}

POPULATION

In 1989, all male workers aged 40-50 and all female workers aged 35-50 employed by EDFGDF were mailed a questionnaire. The 20625 workers who completed this questionnaire made up the GAZEL cohort. The overall response rate was $45 \%$. More men, married people, and managers participated than others. Since 1989, a similar self administered questionnaire has been sent yearly to these volunteers (for details, see $^{33}{ }^{34}$ ). It covered personal characteristics, occupational features including physical exertion at work, nervous exertion, and job satisfaction, tobacco and alcohol consumption, body weight and height, and a list of diseases on which volunteers were asked to indicate those they had suffered from and those they had been treated for during the previous 12 months. In 1995, the questionnaire also included questions concerning the psychosocial aspects of their work-that is, psychological demands, decision latitude, and social support at work. In 1995, 13226 subjects were still working among the respondents, and
12221 of them answered the questions concerning their psychosocial work environment (9001 men and 3220 women). Information about their occupations and education levels was supplied by the personnel department of EDF-GDF.

PSYCHOSOCIAL WORK FACTORS

The self administered questionnaire included 16 items concerning the psychosocial aspects of work, each graded on a four point scale. The items were selected from several sources, ${ }^{7835}$ as being particularly suitable for measuring job stress in a heterogeneous population. Three psychosocial work indices were used (see appendix): psychological demands (a five item indicator measuring job demands, time pressures, and conflicting demands), decision latitude (a six item indicator measuring influence or control over work, job variety, and the possibilities for learning new skills), and social support at work (a five item indicator measuring contacts with coworkers during work and leisure). Cronbach's alpha coefficients were 0.69 in men and 0.70 in women for psychological demands, 0.63 in men and 0.64 in women for decision latitude, and 0.50 in men and women for social support at work. The values for all the items concerning each index were summed, and the summary distribution of values for each index was then dichotomised by the median, for use in analysis.

\section{CARDIOVASCULAR RISK FACTORS}

Six cardiovascular risk factors were examined: the prevalence of hypertension, hyperlipidaemia and diabetes over the past year, overweight, smoking and alcohol consumption at the time of replying to the questionnaire. Hypertension, hyperlipidaemia, diabetes, overweight, and smoking are well known cardiovascular risk factors. ${ }^{36}$ Moderate alcohol consumption has been shown to be inversely related to the risk of coronary heart disease, while heavy consumption could increase the risk. ${ }^{37} 38$ Subjects reported hypertension, hyperlipidaemia and diabetes in their replies, and also their height and weight. Overweight was defined by a body mass index greater than $26.9 \mathrm{~kg} / \mathrm{m}^{2}$ for women, and greater than $27.2 \mathrm{~kg} / \mathrm{m}^{2}$ for men, on the basis of the recommendations by the National Institutes of Health Consensus Development Conference. ${ }^{39}$ Smoking was defined by a consumption of at least one cigarette a day. Alcohol consumption was based on frequency (number of days/week), quantity (glasses/day), and type consumed (wine, beer or spirits). Drinkers were classified into four categories: teetotallers, light drinkers (1-13 drinks/week for men and 1-6 drinks/week for women), intermediate drinkers (14-27 drinks/week for men and 7-20 drinks/week for women), and heavy drinkers (28 drinks/week or more for men and 21 drinks/week or more for women). In the analysis of psychosocial work factors, intermediate and heavy drinkers were considered to be alcohol consumers and were compared with light drinkers. Teetotallers were excluded, because they could be assumed to represent a selected population (including 
Table 2 Distribution of cardiovascular risk factors in 1995

\begin{tabular}{|c|c|c|c|c|}
\hline & \multicolumn{2}{|c|}{ Women } & \multicolumn{2}{|l|}{ Men } \\
\hline & No & $\%$ & No & $\%$ \\
\hline \multicolumn{5}{|l|}{ Hypertension ${ }^{\star}$} \\
\hline No & 3252 & 90.5 & 8435 & 87.6 \\
\hline Yes & 342 & 9.5 & 1197 & 12.4 \\
\hline \multicolumn{5}{|l|}{ Hyperlipidaemia* } \\
\hline No & 3332 & 92.7 & 7831 & 81.3 \\
\hline Yes & 262 & 7.3 & 1801 & 18.7 \\
\hline \multicolumn{5}{|l|}{ Diabetes $\star$} \\
\hline No & 3558 & 99.0 & 9418 & 97.8 \\
\hline Yes & 36 & 1.0 & 214 & 2.2 \\
\hline \multicolumn{5}{|l|}{ Overweight } \\
\hline No & 2899 & 85.3 & 6626 & 71.6 \\
\hline Yes & 500 & 14.7 & 2929 & 28.4 \\
\hline \multicolumn{5}{|l|}{ Smoking status } \\
\hline Non-smokers & 2333 & 65.6 & 3834 & 40.0 \\
\hline Smokers & 571 & 16.0 & 2002 & 20.9 \\
\hline Ex-smokers & 653 & 18.4 & 3745 & 39.1 \\
\hline \multicolumn{5}{|l|}{ Alcohol status } \\
\hline Teetotallers & 824 & 23.1 & 754 & 7.9 \\
\hline Light drinkers & 1887 & 53.0 & 5253 & 54.8 \\
\hline Moderate drinkers & 715 & 20.1 & 2203 & 23.0 \\
\hline Heavy drinkers & 136 & 3.8 & 1369 & 14.3 \\
\hline
\end{tabular}

$\star$ Presence of the disease during the previous 12 months.

ex-drinkers who had stopped drinking because of health problems) and as such, a possible source of bias.

\section{COVARIABLES}

The other variables used in the analysis (table 1) comprised age (men were divided into three five year age groups, and women into four), educational level (seven categories), occupational groups (nine categories for men and six for women), marital status (six categories), number of children (five categories), and physical exertion at work, based on an eight point scale (in tertiles). Smoking status (nonsmokers, smokers, and ex-smokers) and alcohol status (teetotallers, light, intermediate, and heavy drinkers) were used as independent variables in the study of hypertension, hyperlipidaemia, diabetes, and overweight.

STATISTICAL METHODS AND DATA ANALYSIS Separate analyses were carried out for men and women. Statistical analysis was performed using the $\mathrm{SAS}^{40}$ and $\mathrm{BMDP}^{41}$ statistical software. Data were analysed by logistic regression. Hypertension, hyperlipidaemia, diabetes, overweight, smoking, and alcohol consumption were used as dependent variables. In the first stage, each psychosocial work factor (decision latitude, psychological demands, and social support at work) was analysed separately in relation to the above dependent variables. In the second stage, the psychosocial work factors were introduced into a multivariate model to assess the effect of all three simultaneously. Interactions were examined by including the three two way interaction terms: high demands and low latitude, high demands and low support, and low latitude and low support. At each stage, all logistic models included four potential confounding variables: age group, education, occupational group, and physical exertion at work. In addition, the analysis was adjusted for the potential confounding variables specific to each cardiovascular risk factor: (a) smoking status, alcohol status, overweight, hyperlipidaemia, and diabetes in the study of hypertension, (b) smoking status, alcohol status, overweight, and diabetes in the study of hyperlipidaemia, (c) smoking status, alcohol status, overweight, and hyperlipidaemia in the study of diabetes, (d) smoking status, alcohol status, diabetes, hyperlipidaemia, and number of children (for women) in the study of overweight, (e) alcohol status and marital status in the study of smoking, and (f) smoking status and marital status in the study of alcohol consumption. The choice of the confounding factors in each model was based on several assumptions. Hypertension, hyperlipidaemia, diabetes, and overweight are generally considered as independent, but associated, risk factors for cardiovascular disease. ${ }^{42}$ Tobacco and alcohol consumptions are associated, ${ }^{37}$ and they are related to several cardiovascular risk factors, for example alcohol consumption and blood pressure. ${ }^{43}$ Smoking and alcohol consumptions are associated with marital status, and the number of children is associated with overweight in women. ${ }^{44}$

\section{Results}

DESCRIPTION OF THE POPULATION

In 1995, the GAZEL cohort consisted of 15263 volunteers, who had all answered the questionnaire that year. Of them, $87 \%$ were working (that is, 13226 volunteers), $12 \%$ were retired, and $1 \%$ were not working for other reasons (holidays, sick leave, etc). The present study was restricted to the 13226 volunteers who were working in 1995 -that is, $87 \%$ of those who answered the questionnaire, comprising 9632 men and 3594 women. Further details concerning this population are given in table 1, and the distribution of cardiovascular risk factors is shown in table 2 .

Table 3 Prevalence of cardiovascular risk factors according to psychological demands, decision latitude, and social support at work

\begin{tabular}{|c|c|c|c|c|c|c|c|c|c|c|c|c|}
\hline & \multicolumn{6}{|l|}{ Women } & \multicolumn{6}{|l|}{ Men } \\
\hline & $\begin{array}{l}\text { Demands } \\
\text { Low } \\
(n=1445)\end{array}$ & $\begin{array}{l}\text { High } \\
(n=1911)\end{array}$ & $\begin{array}{l}\text { Latitude } \\
\text { Low } \\
(n=1776)\end{array}$ & $\begin{array}{l}\text { High } \\
(n=1623)\end{array}$ & $\begin{array}{l}\text { Support } \\
\text { Low } \\
(n=1893)\end{array}$ & $\begin{array}{l}\text { High } \\
(n=1599)\end{array}$ & $\begin{array}{l}\text { Demands } \\
\text { Low } \\
(n=5096)\end{array}$ & $\begin{array}{l}\text { High } \\
(n=4147)\end{array}$ & $\begin{array}{l}\text { Latitude } \\
\text { Low } \\
(n=4641)\end{array}$ & $\begin{array}{l}\text { High } \\
(n=4688)\end{array}$ & $\begin{array}{l}\text { Support } \\
\text { Low } \\
(n=4856)\end{array}$ & $\begin{array}{l}\text { High } \\
(n=4567)\end{array}$ \\
\hline Hypertension (\%) & 9.41 & 9.63 & 10.42 & $8.38^{\star}$ & 10.51 & $8.51^{\star}$ & 12.17 & 12.59 & 13.45 & $11.54^{\star \star}$ & 12.83 & 12.11 \\
\hline (\%) & 6.64 & 7.54 & 8.11 & $6.28^{\star}$ & 8.03 & 6.38 & 17.90 & 19.41 & 18.16 & 19.33 & 19.01 & 18.39 \\
\hline Diabetes (\%) & 0.69 & 1.15 & 1.13 & 0.92 & 1.27 & $0.63^{\star}$ & 2.22 & 2.24 & 2.37 & 2.11 & 2.29 & 2.15 \\
\hline Overweight (\%) & 13.27 & 15.52 & 14.70 & 14.58 & 14.68 & 14.38 & 28.37 & 28.42 & 28.08 & 28.76 & 26.87 & $30.01^{\star \star \star}$ \\
\hline Smoking (\%) & 14.37 & $17.56^{\star \star}$ & 14.87 & $17.65^{\star}$ & 15.05 & $17.56^{\star}$ & 20.74 & 21.02 & 21.37 & 20.42 & 20.77 & 21.02 \\
\hline $\begin{array}{l}\text { Alcohol } \\
\text { consumption (\%) }\end{array}$ & 31.61 & 30.33 & 31.08 & 30.91 & 32.29 & 29.19 & 41.08 & 39.90 & 41.71 & $39.50^{\star}$ & 39.92 & 41.17 \\
\hline
\end{tabular}

${ }^{\star} \mathrm{p}<0.05 ;{ }^{\star \star} \mathrm{p}<0.01 ;{ }^{\star \star \star} \mathrm{p}<0.001$. 
Table 4 Logistic regression analysis: adjusted odds ratios for cardiovascular risk factors in men

\begin{tabular}{|c|c|c|c|c|c|c|c|c|c|c|c|c|}
\hline & \multicolumn{2}{|c|}{ Hypertension } & \multicolumn{2}{|c|}{ Hyperlipidaemia } & \multicolumn{2}{|c|}{ Diabetes } & \multicolumn{2}{|c|}{ Overweight } & \multicolumn{2}{|c|}{ Smoking } & \multicolumn{2}{|c|}{ Alcohol consumption } \\
\hline & $O R^{\star}$ & $(95 \% C I)$ & ORt & $(95 \% C I)$ & $O R \ddagger$ & $(95 \% C I)$ & $O R S$ & $(95 \% C I)$ & $O R \|$ & $(95 \% C I)$ & $O R^{\star \star}$ & $(95 \% C I)$ \\
\hline \multicolumn{13}{|c|}{ Psychological demands } \\
\hline Low & 1 & & 1 & & 1 & & 1 & & 1 & & 1 & \\
\hline High & 1.01 & $(0.88,1.15)$ & 1.15 & $(1.02,1.28)$ & 1.01 & $(0.75,1.36)$ & 1.03 & $(0.93,1.13)$ & 0.99 & $(0.89,1.10)$ & 0.96 & $(0.87,1.05)$ \\
\hline \multicolumn{13}{|c|}{ Decision latitude } \\
\hline High & 1 & & 1 & & 1 & & 1 & & 1 & & 1 & \\
\hline Low & 1.22 & $(1.06,1.40)$ & 0.88 & $(0.79,1.00)$ & 1.01 & $(0.75,1.37)$ & 0.85 & $(0.77,0.94)$ & 1.03 & $(0.92,1.15)$ & 1.09 & $(0.99,1.19)$ \\
\hline \multicolumn{13}{|c|}{ Social support at work } \\
\hline High & 1 & & 1 & & 1 & & 1 & & 1 & & 1 & \\
\hline Low & 1.14 & $(1.00,1.30)$ & 1.07 & $(0.96,1.20)$ & 1.05 & $(0.78,1.40)$ & 0.85 & $(0.77,0.93)$ & 0.99 & $(0.89,1.10)$ & 0.96 & $(0.87,1.04)$ \\
\hline
\end{tabular}

Note: each psychosocial work variable was analysed separately.

OR: odds ratio adjusted for age, education, occupation, and physical exertion at work CI $95 \%$ confidence intervals

Other covariates:

*Smoking status, alcohol status, overweight, diabetes, hyperlipidaemia.

†Smoking status, alcohol status, overweight, diabetes.

$\ddagger$ Smoking status, alcohol status, overweight, hyperlipidaemia.

§Smoking status, alcohol status, hyperlipidaemia, diabetes.

TAlcohol status, marital status.

${ }^{\star \star}$ Smoking status, marital status.

PSYCHOSOCIAL WORK VARIABLES

Job decision latitude increased with age among men, but not among women. It was related to occupational group and education in both men and women, and the higher the level of education and occupation, the higher the level of decision latitude. Psychological demands were also correlated with occupation and education, and the higher the educational and occupational levels, the higher the level of psychological demands. In addition, social support at work decreased with age in women (results not shown).

Table 3 shows the prevalence of cardiovascular risk factors according to psychological demands, decision latitude, and social support at work. Hypertension was related to low decision latitude for both men and women, and also to low social support at work for women. Hyperlipidaemia was only related to low decision latitude in women. More women with low social support at work suffered from diabetes, whereas in men, overweight was associated with high social support at work. Smoking was associated with high demands, high decision latitude, and high social support at work for women, but no such relations were observed for men. Alcohol consumption was related to low decision latitude among men.

MULTIVARIATE ANALYSIS

Table 4 shows the results for men of the first stage of the analysis, in which each psychosocial work variable was examined separately in relation to the cardiovascular risk factors. In the second stage (table 5), all three psychoso- cial work variables were considered simultaneously in the logistic models. Both tables show adjusted odds ratios. In the first stage (table 4), hypertension was related to low decision latitude and low social support at work. Hyperlipidaemia was associated with high demands and also with high decision latitude. No psychosocial work factor was related to diabetes. More men with high decision latitude and high social support suffered from overweight. No significant relation was observed for smoking and alcohol consumption, except a tendency towards significance $(p=0.07)$ in the relation between alcohol consumption and low decision latitude. As the three psychosocial work factors were considered simultaneously in the models (table 5), the same results were observed for all of them, except for the relation between hypertension and low social support, which was no longer significant. The tendency towards significance remained between alcohol consumption and low decision latitude $(\mathrm{p}=0.06)$. In addition, no significant interactions were found, except for the interaction between high demands and low social support in relation to hyperlipidaemia; the relation between high psychological demands and hyperlipidaemia was modified depending on whether social support at work was high $(\mathrm{OR}=0.94 \mathrm{CI}=0.80,1.12)$ or low $(\mathrm{OR}=1.32$ $\mathrm{CI}=1.00,1.72)$.

The results of the first and second stages of the analysis for women are shown in tables 6 and 7 respectively. In the first stage (table 6), hypertension and diabetes were not related to any of the three psychosocial work variables.

Table 5 Multivariate logistic regression analysis: adjusted odds ratios for cardiovascular risk factors in men

\begin{tabular}{|c|c|c|c|c|c|c|c|c|c|c|c|c|}
\hline & \multicolumn{2}{|c|}{$\begin{array}{l}\text { Hypertension } \\
(n=8501)\end{array}$} & \multicolumn{2}{|c|}{$\begin{array}{l}\text { Hyperlipidaemia } \\
(n=8501)\end{array}$} & \multicolumn{2}{|c|}{$\begin{array}{l}\text { Diabetes } \\
(n=8501)\end{array}$} & \multicolumn{2}{|c|}{$\begin{array}{l}\text { Overweight } \\
(n=8501)\end{array}$} & \multicolumn{2}{|c|}{$\begin{array}{l}\text { Smoking } \\
(n=8791)\end{array}$} & \multicolumn{2}{|c|}{$\begin{array}{l}\text { Alcohol consumption } \\
(n=8109)\end{array}$} \\
\hline & $O R^{\star}$ & $(95 \% C I)$ & ORt & $(95 \% C I)$ & $O R \neq$ & $(95 \% C I)$ & $O R \int$ & $(95 \% C I)$ & OR & $(95 \% C I)$ & $O R^{\star \star}$ & $(95 \% C I)$ \\
\hline \multicolumn{13}{|c|}{ Psychological demands } \\
\hline Low & 1 & & 1 & & 1 & & 1 & & 1 & & 1 & \\
\hline High & 1.00 & $(0.87,1.15)$ & 1.13 & $(1.00,1.26)$ & 1.01 & $(0.75,1.37)$ & 1.05 & $(0.95,1.16)$ & 0.99 & $(0.89,1.10)$ & 0.98 & $(0.89,1.07)$ \\
\hline \multicolumn{13}{|c|}{ Decision latitude } \\
\hline High & 1 & & 1 & & 1 & & 1 & & 1 & & 1 & \\
\hline Low & 1.21 & $(1.05,1.39)$ & 0.87 & $(0.77,0.98)$ & 0.96 & $(0.70,1.31)$ & 0.88 & $(0.79,0.97)$ & 1.05 & $(0.94,1.18)$ & 1.09 & $(0.99,1.20)$ \\
\hline \multicolumn{13}{|c|}{ Social support at work } \\
\hline High & 1 & & 1 & & 1 & & 1 & & 1 & & 1 & \\
\hline Low & 1.12 & $(0.98,1.28)$ & 1.08 & $(0.97,1.21)$ & 1.05 & $(0.78,1.42)$ & 0.83 & $(0.76,0.92)$ & 1.01 & $(0.90,1.12)$ & 0.95 & $(0.87,1.04)$ \\
\hline
\end{tabular}

Note: All three psychosocial work factors were considered simutaneously. See notes in table 4. 
Table 6 Logistic regression analysis: adjusted odds ratios for cardiovascular risk factors in women

\begin{tabular}{|c|c|c|c|c|c|c|c|c|c|c|c|c|}
\hline & \multicolumn{2}{|c|}{ Hypertension } & \multicolumn{2}{|c|}{ Hyperlipidaemia } & \multicolumn{2}{|c|}{ Diabetes } & \multicolumn{2}{|c|}{ Overweight } & \multicolumn{2}{|c|}{ Smoking } & \multicolumn{2}{|c|}{ Alcohol consumption } \\
\hline & $O R^{\star}$ & $(95 \% C I)$ & ORt & $(95 \% C I)$ & $O R \neq$ & $(95 \% C I)$ & ORS & $(95 \% C I)$ & ORף & $(95 \% C I)$ & $O R^{\star \star}$ & $(95 \% C I)$ \\
\hline \multicolumn{13}{|c|}{ Psychological demands } \\
\hline Low & 1 & & 1 & & 1 & & 1 & & 1 & & 1 & \\
\hline High & 0.89 & $(0.68,1.16)$ & 1.11 & $(0.83,1.50)$ & 1.64 & $(0.71,3.79)$ & 1.26 & $(1.02,1.57)$ & 1.35 & $(1.10,1.65)$ & 0.90 & $(0.75,1.08)$ \\
\hline \multicolumn{13}{|c|}{ Decision latitude } \\
\hline High & 1 & & 1 & & 1 & & 1 & & 1 & & 1 & \\
\hline Low & 1.25 & $(0.95,1.64)$ & 1.39 & $(1.03,1.87)$ & 1.21 & $(0.57,2.58)$ & 0.88 & $(0.71,1.09)$ & 0.81 & $(0.66,0.99)$ & 1.09 & $(0.91,1.30)$ \\
\hline \multicolumn{13}{|c|}{ Social support at work } \\
\hline High & 1 & & 1 & & 1 & & 1 & & 1 & & 1 & \\
\hline Low & 1.10 & $(0.85,1.42)$ & 1.28 & $(0.96,1.69)$ & 1.57 & $(0.72,3.41)$ & 0.97 & $(0.79,1.19)$ & 0.88 & $(0.73,1.07)$ & 1.15 & $(0.97,1.36)$ \\
\hline
\end{tabular}

Note: each psychosocial work variable was analysed separately.

OR: odds ratio ajusted for age, education, occupation, and physical exertion at work CI $95 \%$ confidence intervals.

Other covariates:

${ }^{\star}$ Smoking status, alcohol status, overweight, diabetes, hyperlipidaemia.

†Smoking status, alcohol status, overweight, diabetes.

$\ddagger$ Smoking status, alcohol status, overweight, hyperlipidaemia.

§Smoking status, alcohol status, hyperlipidaemia, diabetes, number of children.

TAlcohol status, marital status.

${ }^{\star \star}$ Smoking status, marital status.

Hyperlipidaemia was associated with low decision latitude. More women with high psychological demands were overweight. Smoking was related to high demands, and also with high decision latitude. A tendency towards significance $(p=0.12)$ was found in the relation between alcohol consumption and low social support at work. In the second stage (table 7), the same results were observed, except for the relation between alcohol consumption and low social support, which became significant. No interaction was found between psychological demands, decision latitude or social support at work for women.

\section{Discussion}

The relations shown in this study between psychosocial work variables and cardiovascular risk factors were somewhat different for men and women. However, the job strain model, which postulates that the combination of high psychological demands and low decision latitude increases the risk of cardiovascular disease, was not supported by our results.

These results are presented with the following reservations:

(1) The response rate for the first self administered questionnaire in 1989 was $45 \%$ (20 625 replies), which can be considered satisfactory for a mailed questionnaire. In 1995, it was $74 \%$ of the 1989 rate (that is, 15263 replies). Although the non-participants probably had a lower health status than the participants, ${ }^{45}$ it seems unlikely that persons with cardiovascular risk factors participated in the study differentially, according to their psy- chosocial work environment. Moreover, participants and non-participants did not differ according to chemical exposures recorded by occupational physicians-that is, independently of subjects. ${ }^{46}$ Thus, it seems unlikely that they differed according to other work related factors.

(2) Assessment of psychosocial work factors was based on self reporting, which reflects only partly objective work environment. Firstly, the subject's perception of their psychosocial work environment may be more important than objective assessment, and secondly, self reporting of psychosocial work factors allows the within occupational variance to be taken into account, which is neglected in a work organisation exposure matrix. ${ }^{47}$ Nevertheless, our scale of social support at work suffered from some weaknesses. This scale only measured frequency of contacts with coworkers, neither the satisfaction with the support received, nor the support from supervisor.

(3) Cardiovascular risk factors were also assessed by self reporting. Some of these reports concerning ischaemic heart diseases were compared with the entries in the EDFGDF disease register, and showed strong concordance: among the 12680 subjects who responded to the self administered questionnaires each year from 1990 and 1994, the sensitivity was $95.5 \%$ and the specificity was $99.7 \%$ as regards incidence of myocardial infarction and angina pectoris. This led us to think that the self reported health data in this cohort were reliable. Moreover, as EDF-GDF workers undergo a yearly medical examination

Table 7 Multivariate logistic regression analysis: adjusted odds ratios for cardiovascular risk factors in women

\begin{tabular}{|c|c|c|c|c|c|c|c|c|c|c|c|c|}
\hline & \multicolumn{2}{|c|}{$\begin{array}{l}\text { Hypertension } \\
(n=2958)\end{array}$} & \multicolumn{2}{|c|}{$\begin{array}{l}\text { Hyperlipidaemia } \\
(n=2958)\end{array}$} & \multicolumn{2}{|c|}{ Diabetes $(n=2958)$} & \multicolumn{2}{|c|}{$\begin{array}{l}\text { Overweight } \\
(n=2947)\end{array}$} & \multicolumn{2}{|c|}{ Smoking $(n=3106)$} & \multicolumn{2}{|c|}{$\begin{array}{l}\text { Alcohol consumption } \\
(n=2391)\end{array}$} \\
\hline & $O R^{\star}$ & $(95 \% C I)$ & ORt & $(95 \% C I)$ & $O R \ddagger$ & $(95 \% C I)$ & $O R S$ & $(95 \% C I)$ & ORף & $(95 \% C I)$ & $O R^{\star \star}$ & $(95 \% C I)$ \\
\hline \multicolumn{13}{|c|}{ Psychological demands } \\
\hline Low & 1 & & 1 & & 1 & & 1 & & 1 & & 1 & \\
\hline High & 0.88 & $(0.67,1.16)$ & 1.11 & $(0.82,1.49)$ & 1.51 & $(0.65,3.53)$ & 1.27 & $(1.02,1.59)$ & 1.32 & $(1.08,1.63)$ & 0.88 & $(0.73,1.06)$ \\
\hline \multicolumn{13}{|c|}{ Decision latitude } \\
\hline High & 1 & & 1 & & 1 & & 1 & & 1 & & 1 & \\
\hline Low & 1.19 & $(0.90,1.58)$ & 1.42 & $(1.04,1.93)$ & 1.34 & $(0.59,3.03)$ & 0.91 & $(0.73,1.13)$ & 0.80 & $(0.65,0.99)$ & 1.04 & $(0.86,1.25)$ \\
\hline \multicolumn{13}{|c|}{ Social support at work } \\
\hline High & 1 & & 1 & & 1 & & 1 & & 1 & & 1 & \\
\hline Low & 1.05 & $(0.80,1.38)$ & 1.21 & $(0.90,1.62)$ & 1.81 & $(0.78,4.22)$ & 0.97 & $(0.78,1.21)$ & 0.90 & $(0.74,1.09)$ & 1.20 & $(1.00,1.43)$ \\
\hline
\end{tabular}

Note: All three psychosocial work factors were considered simultaneously. See notes in table 6. 
with an occupational physician that includes a physical examination, urine collection, and blood pressure measurement, the GAZEL volunteers are presumably aware of their health problems. However, the self reporting from which almost all the data in this study were derived can involve difficulties of interpretation. For instance, the presence of cardiovascular risk factors may indeed affect the way in which people perceive their working environment. ${ }^{48}$ As regards self reporting of height and weight, 6940 of the 13226 respondents, who were working in 1995, were measured by occupational physicians. Although comparisons between self reports and measurements have showed significant overestimation of height $(0.4 \mathrm{~cm}$ in mean $)$ and underestimation of weight $(0.6 \mathrm{~kg}$ in mean) for both men and women, analyses carried out with these measurements have provided the same results as the ones presented in this paper.

(4) Our classification of subjects with regard to the exposure to psychosocial work variables was based on a single evaluation rather than on the individual's cumulative work history. EDFGDF workers were chosen for the study because of the stability of the company's work force. Only $0.4 \%$ of the participants have been lost to follow up from 1989 to 1995: 31 subjects who did not want to participate any longer and 51 who resigned from the company.

(5) In the cross sectional analysis, we also had to deal with problems of selection like the "healthy worker effect", which may mean that subjects with health problems are selected for jobs involving low levels of strain. Such phenomenon would, of course, weaken the observed associations.

(6) One of our chief concerns was to avoid a spurious relation between psychosocial work variables and cardiovascular risk factors resulting from confounding factors. As our regression analyses controlled for most of the known or suspected risk factors-age, education, occupation, physical exertion at work, and also overweight, alcohol consumption, smoking behaviour, hyperlipidaemia, diabetes and in some cases, the number of children and marital status - the relations between these variables and cardiovascular risk factors cannot account for the effect of psychosocial work variables. It is possible that some confounding factors were disregarded, such as sociocultural factors, diet, personality traits, like the Type A Behaviour Pattern, ${ }^{49}$ or other cardiovascular risk factors, but it seems unlikely that these factors would explain the observed relations. In addition, the stability of these relations before and after adjustment prompts us to think that confounding factors do not "explain away" the associations between psychosocial characteristics of work and cardiovascular risk factors; this stability confirms the previous results reported by Johnson et al. ${ }^{850}$ Moreover, adjustment for confounding variables may represent overcontrol and thus lead to an underestimation of risk, as these variables, for example smoking, may be part of the causal pathway between exposure to

\section{KEY POINTS}

- Psychosocial factors at work were found to be associated with cardiovascular risk factors, the pattern of associations being different for men and women.

- Psychosocial work environment is an important contributor to health (especially cardiovascular health) and preventive measures should focus on it.

psychosocial work characteristics and cardiovascular risk factors.

Despite these limitations, the results of this study confirm some of the previous findings for the relation between psychosocial aspects of work and cardiovascular risk factors.

As regards hypertension, the results of existing studies on the relation between psychosocial work factors and blood pressure are controversial. Most authors examined casual blood pressure in relation to job strain and found no significant associations. However, some used an ambulatory blood pressure monitor and found significant associations with job strain. ${ }^{19-2325}$ Our study confirms some of the previous results for the relation between low decision latitude and hypertension in men, as shown in the study based on a meta analysis by Pieper et $a l,{ }^{51}$ who found that casual systolic blood pressure was related to decision latitude. In women, hypertension was not related to any psychosocial work factor in our study. Among the very few studies of women, Theorell et $a l^{24}$ observed in 56 female hospital workers that job strain was associated with systolic and diastolic blood pressure during working hours, and also with diastolic blood pressure at rest, but in the study by Light et $a l,{ }^{20}$ high job strain was not associated with any increase in blood pressure in women.

The prevalence of hyperlipidaemia was found to increase when high levels of psychological demands were combined with low social support at work for men, and with low decision latitude for women. Surprisingly, a low level of decision latitude was observed to protect men from hyperlipidaemia. The few authors who examined the relation between psychosocial work factors and total serum cholesterol (or in some cases, high or low density lipoproteins, or triglycerides) found no significant relations, ${ }^{14} 285152$ except for those reported in the retrospective study by Theorell et al, ${ }^{12}$ who observed that the combination of high psychological demands and low decision latitude was significantly associated with serum cholesterol concentrations.

As regards the relations between psychosocial work factors and diabetes, these were not significant in our study. As far as we know, they have not been examined in any other investigation.

With respect to overweight, we showed here that low decision latitude and low social support at work had a protective effect on overweight among men, which was unexpected. However, the relation may partly be explained, as in our study high social support at 
work meant close and frequent social contacts with colleagues. Men with high levels of decision latitude or social support may have more social occasions to gain weight. In comparable social and occupational environment, women probably watch their weight more closely. Among women, high psychological demands were associated with overweight. In most previous studies, no relation was found between psychosocial work factors and overweight. ${ }^{12} 142953$ Nevertheless, Netterstrom et $a l^{28}$ observed an association between "objective" job strain and body mass index. In this connection, Georges et $a b^{4}$ found that, after controlling for education, job strain was associated with fatness but not with central body fat distribution, unlike that could be expected from the model of Björntorp, ${ }^{55}$ which shows how psychosocial stress in general can contribute to a central pattern of fat distribution.

Among men, smoking behaviour was not related to psychosocial work variables, but two associations were observed among women: those with high decision latitude and high psychological demands were more likely to be smokers. Whereas the relation between high psychological demands and smoking could be expected, the one between high decision latitude and smoking is more surprising, because occupation was taken into account. No interaction was found among either men or women between high demands and low latitude, neither was social support at work in any way related to smoking. Some authors did not find any relation between psychosocial aspects of work and smoking, ${ }^{12}{ }^{14}$ whereas others did. . $^{29} 30515357-60$ In particular, our results confirm the report by Karasek $^{59}$ of a relation between increased job control and smoking in white collar female workers.

There are few investigations of the relation between psychosocial work factors and alcohol consumption but in most of them, no significant relation was found between these variables. ${ }^{12} 1429{ }^{57}$ Bromet et $a l^{61}$ reported that in men, the combination of high job demands and low decision latitude was important in predicting the occurrence of alcohol related problems. Our results showed an association between low decision latitude and alcohol consumption in men, and also a relation between low social support at work and alcohol consumption in women.

In conclusion, this study provided cross sectional results on the relation between the psychosocial aspects of work and cardiovascular risk factors in a large heterogeneous population. Women as well as men were studied, in contrast with previous studies, in which the potential impact of occupational stress on the health of women workers was often neglected. Our study showed that certain psychosocial aspects of work might be related to cardiovascular risk factors, and confirmed that both direct and indirect mechanisms could be involved in the relation between the psychosocial working environment and cardiovascular disease. However, the study of the effects of this environment on cardiovascular risk factors needs further investigation. For this purpose, the GAZEL cohort will continue to be followed up, and forthcoming prospective data will provide an opportunity to explore the relations between psychosocial work characteristics and cardiovascular risk factors on the one hand and morbidity on the other using both self reports and the ischaemic heart disease register of EDF-GDF.

The authors wish to thank the medical committee of EDF-GDF, all the GAZEL volunteers, and Drs Anne Chevalier, Coralie Ravault, Marie Zins for providing ischaemic heart disease register data.

Funding: none.

Conflicts of interest: none.

\section{Appendix \\ Contents of the questionnaire on which the present study was based \\ Questions concerning psychological job demands: \\ My work requires me to work very fast \\ My work requires me to work very hard \\ I am asked to do too much work \\ I have enough time to do my work \\ I receive no conflicting demands \\ Questions concerning decision latitude: \\ My work requires me to learn new skills \\ My work requires a high level of skills \\ My work requires creativity \\ My work is repetitive \\ I am free to decide what I am going to do on the job \\ I am free to decide the amount of work I am going to do \\ Questions concerning social support at work: \\ Can you talk to your coworkers during breaks? \\ Can you leave your work to talk to your coworkers? \\ Does your work require you to have many contacts with your coworkers? \\ How often do you meet your coworkers outside the work place?}

When did you last meet one of your coworkers at home?

1 Karasek RA. Job demands, job decision latitude, and mental train: implications for job redesign. Administrative Science Quarterly 1979;24:285-308.

2 Alfredsson L, Karasek R, Theorell T. Myocardial infarction risk and psychosocial work environment: an analysis of the male Swedish working force. Soc Sci Med 1982;16:463-7.

3 Alfredsson L, Theorell T. Job characteristics of occupations and myocardial infarction risk: effect of possible confounding factors. Soc Sci Med 1983;17:1497-503.

4 Alfredsson L, Spetz CL, Theorell T. Type of occupation and near-future hospitalization for myocardial infarction and some other diagnoses. Int $\mathcal{F}$ Epidemiol 1985; 14:378-88.

5 Haan MN. Job strain and ischaemic heart disease: an epidemiologic study of metal workers. Ann Clin Res 1988;20: miologic

6 Hammar N, Alfredsson L, Theorell T. Job characteristics and the incidence of myocardial infarction. Int $\mathcal{f}$ Epidemiol 1994;23:277-84.

7 Johnson JV, Hall EM. Job strain, work place social support, and cardiovascular disease: a cross-sectional study of a random sample of the Swedish working population. Am F Public Health 1988;78:1336-42.

8 Johnson JV, Hall EM, Theorell T. Combined effects of job strain and social isolation on cardiovascular disease morbidity and mortality in a random sample of the Swedish male working population. Scand $\mathcal{F}$ Work Environ Health 1989;15:271-9.

9 Karasek RA, Baker D, Marxer F, Ahlbom A, Theorell T. Job decision latitude, job demands, and cardiovascular disease: a prospective study of Swedish men. Am f Public Health 1981;71:694-705.

10 Karasek RA, Theorell T, Schwartz JE, Schnall PL, Pieper $\mathrm{CF}$, Michela JL. Job characteristics in relation to the prevalence of myocardial infarction in the US Health Examination Survey (HES) and the Health and Nutrition Examination Survey (HES) and the Health and Nutrition Examina-
tion Survey (HANES). Am $\mathcal{F}$ Public Health 1988;78:91018.

11 LaCroix A, Haynes S. Occupational exposure to high demand/low control work and coronary heart disease incidence in the Framingham cohort. $A m \mathcal{F}$ Epidemiol 1984;120:481

12 Theorell T, Hamsten A, de Faire A, Orth-Gomer K, Perski A. Psychosocial work conditions before myocardial infarction in young men. Int $\mathcal{F}$ Cardiol 1987;15:33-46.

13 Theorell T, Perski A, Orth-Gomer K, Hamsten A, de Faire $\mathrm{U}$. The effects of the strain of returning to work on the risk of cardiac death after a first myocardial infarction before the age of 45. Int $\mathcal{F}$ Cardiol 1991;30:61-7.

14 Reed DM, Lacroix AZ, Karasek RA, Miller D, MacLean CA. Occupational strain and the incidence of coronary heart disease. Am f Epidemiol 1989;129:495-502.

15 Alterman T, Shekelle RB, Vernon SW, Burau KD. Decision latitude, psychologic demand, job strain, and coronary heart disease in the Western Electric Study. Am $\mathcal{F}$ Epidemiol 1994;139:620-7. 
16 Schnall PL, Landsbergis PA, Baker D. Job strain and Schnall PL, Landsbergis PA, Baker D. Job strain and cardiovascul.

17 Kristensen TS. The demand-control-support model: Methodological challenges for future research. Stress Med 1995; 11:17-26.

18 Kasl SV. The influence of the work environment on cardiovascular health: a historical, conceptual, and methodological perspective. F Occup Health Psychol 1996;1:42-56.

19 Landsbergis PA, Schnall PL, Warren K, Pickering TG, Schwartz JE. Association between ambulatory blood pressure and alternative formulations of job strain. Scand $\mathcal{F}$
Work Environ Health 1994;20:349-63.

20 Light KC, Turner JR, Hinderliter AL. Job strain and ambulatory work blood pressure in healthy young men and women. Hypertension 1992;20:214-18.

21 Schnall PL, Pieper C, Schwartz JE, et al. The relationship between job strain, workplace diastolic blood pressure, and
left ventricular mass index. $\mathcal{F}$ Am Med Assoc 1990;263: 1929-35.

22 Schnall PL, Schwartz JE, Landsbergis PA, Warren K, Pickering TG. Relation between job strain, alcohol, and ambu-
latory blood pressure. Hypertension 1992;19:488-94.

23 Theorell T, de Faire U, Johnson J, Hall E, Perski A, Stewart W. Job strain and ambulatory blood pressure profiles. Scand 7 Work Environ Health 1991;17:380-5.

24 Theorell T, Ahlberg-Hulten G, Jodko M, Sigala F, de la Torre B. Influence of job strain and emotion on blood pressure in female hospital personnel during workhours. Scand $\mathcal{7}$ Work Environ Health 1993;19:313-18.

25 Van Egeren LF. The relationship between job strain and blood pressure at work, at home, and during sleep. Psychosomatic Med 1992;54:337-43.

26 Härenstam AB, Theorell TPG. Work conditions and urinary excretion of catecholamines - A study of prison staff in Sweden. Scand $\mathcal{F}$ Work Environ Health 1988;14:257staff

27 Brunner E, Davey Smith G, Marmot M, Canner R, Beksinska M, O'Brien J. Childhood social circumstances and psyska $\mathrm{M}$, O Brien J. Childhood social circumstances and psyphosocial and behavioural factors as det

28 Netterstrom B, Kristensen TS, Damsgaard MT, Olsen O, Sjol A. Job strain and cardiovascular risk factors: a cross-sectional study of employed Danish men and women $\mathrm{Br}$ F Ind Med 1991;48:684-9.

29 Cohen S, Schwartz JE, Bromet EJ, Parkinson DK. Mental health, stress, and poor health behaviours in two community samples. Prev Med 1991;20:306-15.

30 Green KL, Johnson JV. The effects of psychosocial work organization on patterns of cigarette smoking among male chemical plant employees. Am $\mathcal{F}$ Public Health 1990;80 1368-71.

31 Chapman A, Mandryk JA, Frommer MS, Edye BV, Ferguson DA. Chronic perceived work stress and blood pressure among Australian government employees. Scand f Work Environ Health 1990;16:258-69.

32 Caplan RD, Cobb S, French JRP. Relationships of cessation of smoking with job stress, personality, and social support. of smoking with job stress, person.

33 Goldberg M, Leclerc A, Chastang JF, et al. Mise en place d'une cohorte épidémiologique à Electricité De France Gaz De France. Recrutement des volontaires. Rev Epidemiol Santé Publique 1990;38:265-8.

34 Goldberg M, Leclerc A, Chastang JF, et al. Mise en place d'une cohorte épidémiologique à Electricité De France Gaz De France. Principales caractéristiques de l'échantillon. Rev Epidemiol Santé Publique 1990;38:37880.

35 Karasek R, Theorell T. Healthy work: stress, productivity, and the reconstruction of working life. New York, NY: Basic Books, 1990.

36 Dawber TR, Kannel WB. The Framingham study. An epidemiological approach to coronary heart disease. Circulation 1966;34:553-5.

37 Dyer AR, Stamler J, Paul O, et al. Alcohol consumption, cardiovascular risk factors, and mortality in two Chicago cardiovascular risk factors, and mortality in two Chiologic studies. Circulation 1977;56:1067-74.
38 Marmot MG. Alcohol and coronary heart disease. Int f Epidemiol 1984;13:160-7.

39 Burton BT, Foster WR, Hirsch J, Van Itallie TB. Health implications of obesity: an NIH consensus development conference. Int f Obesity 1985;9:155-69.

40 SAS Institute Inc. SAS/STAT User's Guide. Release 6.03 Edition. Cary, NC:SAS Institute Inc, 1988.

41 BMDP Statistical Software Inc. BMDP Statistical Software Manual. Vol 2. Los Angeles, CA: BMDP Statistical Software Inc, 1990.

42 Zimmet P, Baba S. Central obesity, glucose intolerance and other cardiovascular disease risk factors: an old syndrome rediscovered. Diab Res Clin Pract 1990;10:S167-71.

43 Marmot MG, Elliott P, Shipley MJ, et al. Alcohol and blood pressure: the Intersalt study. BMF 1994;308:1263-7.

44 Heliövaara M, Aromaa A. Parity and obesity. F Epidemiol Community Health 1981;35:197-9.

45 Goldberg M, Chastang JF, Bugel I, Leclerc A. Facteurs socio-démographiques, professionnels et de santé associés au taux de participation à la cohorte GAZEL (EDF-GDF). Rev Epidemiol Santé Publique 1995; 43 (suppl 1):12.

46 Goldberg M, Leclerc A, Bugel I, et al. Cohorte Gazel 20000 volontaires d'EDF-GDF pour la recherche médicale. Bilan 1989-1993. Paris: Editions INSERM, 1994:220.

47 Schwartz JE, Pieper CF, Karasek RA. A procedure for linking psychosocial job characteristics data to health surveys. Am F Public Health 1988;78:904-9.

48 Theorell T, Alfredsson L, Knox S, Perski A, Svensson J, Waller D. On the interplay between socioeconomic factors, personality and work environment in the pathogenesis of cardiovascular disease. Scand $\mathcal{F}$ Work Environ Health 1984; 10:373-80.

49 Matthews KA, Haynes SG. Type A Behaviour Pattern and coronary disease risk. Am 7 Epidemiol 1986;123:923-60.

50 Johnson JV, Stewart W, Hall EM, Fredlund P, Theorell T. Long-term psychosocial work environment and cardiovascular mortality among Swedish men. Am 7 Public Health 1996;86:324-31.

51 Pieper C, Lacroix AZ, Karasek RA. The relation of psychosocial dimensions of work with coronary heart disease risk factors: a meta-analysis of five United States data bases. $\mathrm{Am}$ $\mathcal{f}$ Epidemiol 1989;129:483-94

52 Chesney MA, Sevelius G, Black GW, Ward M, Swan GE, Rosenman RH. Work environment, type A behaviour, and coronary heart disease risk factors. F Occup Med 1981;23. $551-5$.

53 House JS, Strecher V, Metzner HL, Robbins CA. Occupational stress and health among men and women in the Tecumseh Community Health Study. $f$ Health Soc Behav 1986;27:62-77.

54 Georges E, Wear ML, Mueller WH. Body fat distribution and job stress in Mexican-American men of the Hispanic Health and Nutrition Examination Survey. Am f Hum Biol 1992;4:657-67.

55 Björntorp P. Visceral fat accumulation: the missing link between psychosocial factors and cardiovascular disease ? $\mathcal{F}$ Intern Med 1991;230:195-201.

56 Björntorp P. Visceral obesity: a "civilization syndrome". Obesity Res 1993;1:206-22.

57 Conway TL, Vickers RR, Ward HW, Rahe RH. Occupational stress and variation in cigarette, coffee, and alcohol consumption. F Health Soc Behav 1981;22:155-65.

58 Johansson G, Johnson JV, Hall EM. Smoking and sedentary behaviour as related to work organization. Soc Sci Med 1991;32:837-64.

59 Karasek R. Lower health risk with increased job control among white collar workers. Fournal of Organizational Behaviour 1990;11:171-85.

60 Westman M, Eden D, Shirom A. Job stress, cigarette smoking and cessation: the conditioning effects of peer support. Soc Sci Med 1985;20:637-44.

61 Bromet EJ, Dew MA, Parkinson DK, Schulberg HC. Predictive effects of occupational and marital stress on the mental health of a male workforce. Fournal of Organizational Behaviour 1988;9:1-13. 